Business Review- A Journal of Business Administration Discipline, Khulna University, Volume: 12, Number: 1E2, January-December 2017, pp.1-8 (Print ISSN : 1811-3788; Online ISSN : 2664-3502)

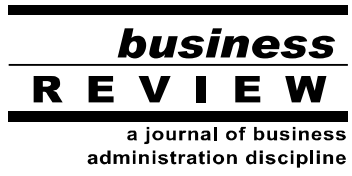

\title{
Understanding Users' Intention to Use Mobile Financial Services: A Study in Khulna City \\ ${ }^{1}$ Md. Khashrul Alam
}

\begin{abstract}
Purpose: Mobile Financial Services are such applications of mobile computing which provide customers the support that is needed to access their bank accounts and bank anywhere and anytime using a mobile handheld device such as a mobile phone. Mobile Financial Services remove space and time limitations from banking activities such as checking account balances or transferring money from one account to another. The study tries to understand users' level of intension to use mobile financial services in Khulna city.

Methodology: Data have been collected from 110 respondents out of which 35 respondents are agents and rest is from different professions. All mobile financial service users in Khulna city have been assumed as population for the study. There has been no demographic barrier for the mobile financial services users to be taken or to be given priority. A structured questionnaire has been administered among the respondents to collect the data. There are 7 variables that have been interviewed among the respondents. These variables are taken from 'Technology acceptance model' and 'Theory of reasoned action'. Correlation and multiple regression analysis are applied to understand the intension of the users.
\end{abstract}

Findings: The study finds that there are strong relationships among the variables. It also shows that trust has strong relation with intention to use mobile financial services.

Value: Different stakeholders like mobile financial service providers, mobile operators, regulatory authorities, government and others will get benefit from the study.

Keywords: Financial services, System quality, Perceived usefulness, Credibility, Trust.

\section{Introduction and background}

Mobile financial services (MFS) also known as mobile banking refers to an electronic banking innovation business using mobile network and mobile communication technology to realize connection of mobile phones and other mobile devices banking system as well as getting a variety of financial services through the mobile interface or SMS. This new mode allows the user to access to financial services in any time, place and context, there by changing the rules of competition in the inter-bank. The banks are no longer just concerned about the number of outlets and coverage, but more focused on providing professional and personalized service. There are around 160 million people in Bangladesh, of which only 13 percent have bank accounts where as more than 95 percent are mobile phone users. Banks can now offer the banking services to rural and unbanked population through mobile phone. It is the most recent and ground-breaking service by the banks. Access to formal financial services can help households to better plan and manage their lives. Mobile Financial System (MFS) offers the opportunity to build another channel beyond the bank branch and ATM network to enable millions to have easier access to the formal banking system. Bangladesh began its mobile banking journey in 2011. The primary goal of mobile banking, also commonly referred to as mobile financial services (MFS), is financial inclusion - reaching the unbanked population with appropriate financial services. However, in the initial stages of market development, funds transfer services have been the most predominant form of MFS in Bangladesh (Prothom-alo, 2014). Let's see the major players and their operation with a brief table.

Anaysi and Otubu (2009) have shown the economic effect of mobile banking and found out that it is offering different services to its customers. It helps to manage money without handling cash. They have also got the great scope of extending mobile banking business to contribute to the economic development. Astha and Arvind (2010) in the paper "Evaluation of Mobile Banking Regulation" have described that mobile banking is a new invention for unmet demand of the customers especially for the poor. They have emphasized for mobile banking regulation to

\footnotetext{
${ }^{1}$ Professor, Business Administration Discipline, Khulna-9208, Email: khashru74@gmail.com
} 
avoid some risks banks and telecommunications face such as liquidity risk, credit risk, privacy risk, inoperability risk etc. They think regulation will help reduce the risk level and the institutions reach the top of the industry, but regulation should not minimize the benefits of mobile banking. As millions are using mobile banking services in al over the country it is important to know users level of intention to use mobile financial services. Based on this premise the study has been initiated in Khulna city.

\section{Literature Review and Theoretical Framework}

The study uses several models to understand users' intension to use mobile financial services offered by different providers. The researchers mostly relies on the technology acceptance model are shortly known as TAM for conducting the study. The Technology Acceptance Model was developed based on the Theory of Reasoned Action shortly known as 'TRA' by Fishbein and Ajzein in 1975. Tam has been used widely to understand user acceptance of new technologies. As defined by Devis (1989), there are two basic determinants which are 'Perceived usefulness' and 'Perceived ease of use'. They are instrumental in explaining the user's intention and behavior towards the use of new technology.

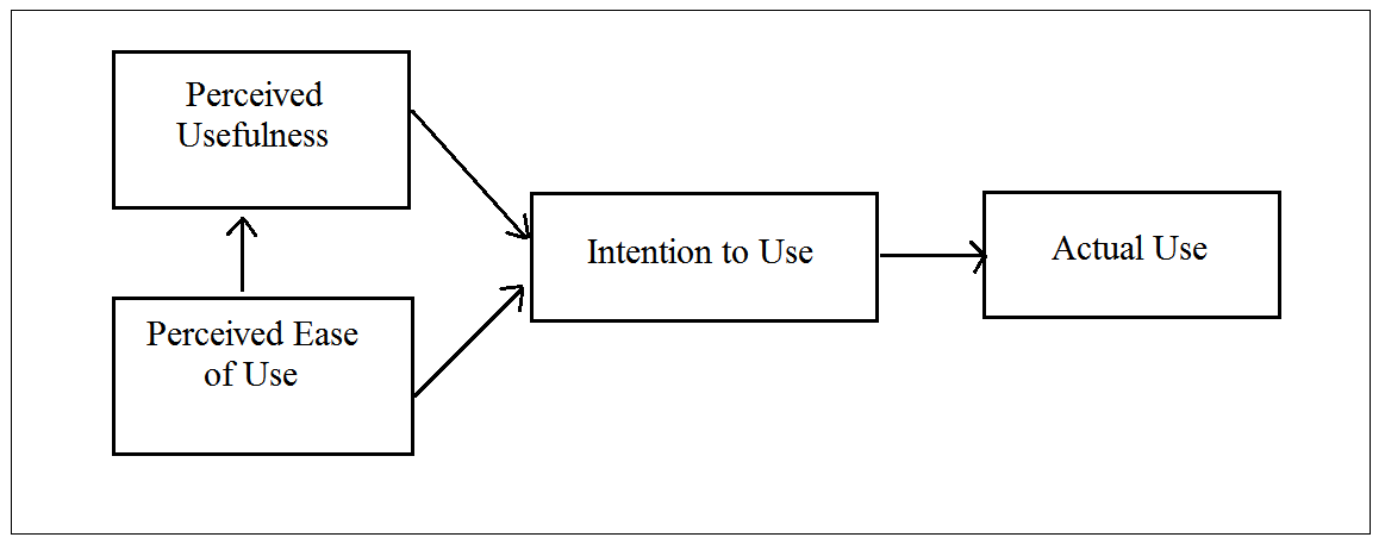

Figure 1: Technology Acceptance Model (TAM)

Source: Davis, Bagozzi and Warshaw (1989)

Perceived usefulness is defined as 'The degree to which a person believes that using a particular system would enhance someone's job performance'. And perceived ease of use is defined as 'the degree to which a person believes that using particular system would be free from effort'. There are more variables which can affect usefulness, ease of use and user acceptance. Because these two determinants may not fully explain the factors, which can predict the acceptance of a new technology such as 'mobile banking'. Prior studies have added more construct with the original TAM model. The extended TAM model includes perceived usefulness, perceived ease of use, perceived credibility, perceived self-efficacy and perceived financial cost.

TAM posits that two particular beliefs - perceived usefulness and perceived ease of use - are primarily relevant to technology acceptance behaviors (Bruner \& Kumar 2005;Davis, 1989; King \& He, 2006). According to Davis, Bagozzi and Warshaw (1989), perceived usefulness is defined as the prospective user's subjective probability that using a specific application system will increase his or her job performance. Perceived ease of use refers to the degree to which the prospective user expects the target system to be free of effort. Previous research suggested two determinants that are especially important. The first determinant is that individuals tend to use an application to the extent they believe it will help them do their job better. This variable is referred to as perceived usefulness (Davis, 1989).Second, even if potential users believe that a given application is useful they may feel that the system is too hard to use and that the performance benefits of usage are outweighed by the effort of using the application (Davis, 1989). Therefore, in addition to usefulness, usage is theorized as being influenced by ease of use. Similar to the theory of reasoned action, TAM proposes that attitude towards using technology is jointly determined by perceived usefulness and ease of use. TAM does not include TRA's subjective norms as determinants of behavioral intention 
Business Review- A Journal of Business Administration Discipline, Khulna University, Volume: 12, Number: 1E2, January-December 2017, pp.1-8 (Print ISSN : 1811-3788; Online ISSN : 2664-3502)

since this is one of the least understood aspects of TRA (Davis, Bagozzi, \&Warshaw 1989; Schepers \& Wetzels 2007).

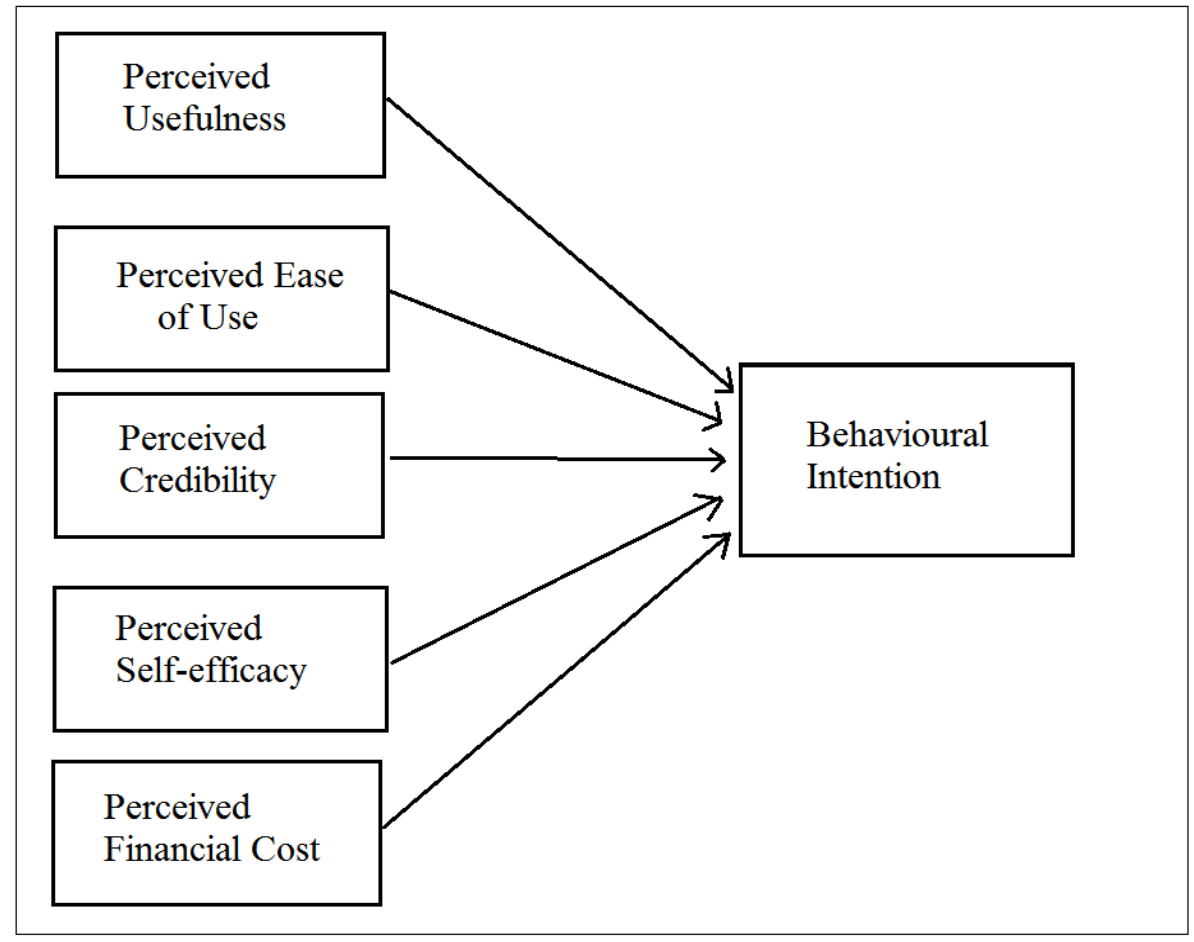

Figure 2: Behavioral Intention to Use

Source: Luarn and Lin (2004)

Luarn and Lin added these constructs into original TAM model to facilitate understanding of the intention to use mobile banking in Taiwan.

\section{Objectives of the Study}

1. To understand users' intention to use (MFS) mobile financial services

2. To know who are major players in terms of mobile operator and mobile financial service providers.

\section{Methods}

As stated previously this study is based on the Technology Acceptance Model (TAM) and the Theory of Reasoned Action (TRA) (Ajzen \& Fishbein 1980) and (Davis, 1989). The researcher uses a previously tested questionnaire that Luarn and Lin (2005) and Gu, Lee and Suh (2009) Talukder, Majharul; Quazi, Ali; and Sathye, Milind (2014) used in Taiwan, the Republic of Korea, and Australia respectively. The items used to design the questionnaire were adopted and modified from previously developed questionnaire of various study. All mobile financial service users in Khulna city have been assumed as population for the study. There has been no demographic barrier for the mobile financial services users to be taken or to be given priority. The size of the sample is 110 . Among them at least 35 agents have been taken from different places of Khulna city. Randomly selected 75 from different profession have been taken from different age of people. The sampling has been taken randomly. Structured questionnaire has been administered among the respondents to collect the data. It has been measured by 5 points likert scale. There are 7 variables that have been interviewed among the respondents. These variables are taken from 'Technology acceptance model' and 'Theory of reasoned action'. Data have been analyzed through various statistical techniques i.e. correlation and regression analysis. Software like MS Excel SPSS 20 has been used to derive the result. 
Business Review- A Journal of Business Administration Discipline, Khulna University, Volume: 12, Number: 1E2, January-December 2017, pp.1-8 (Print ISSN : 1811-3788; Online ISSN : 2664-3502)

\section{Data Analysis and Interpretation}

Demographic Analysis: The study surveys 110 respondents. It finds that respondent have different Educational background. Most respondents have HSC degree and bachelor degree respectively.

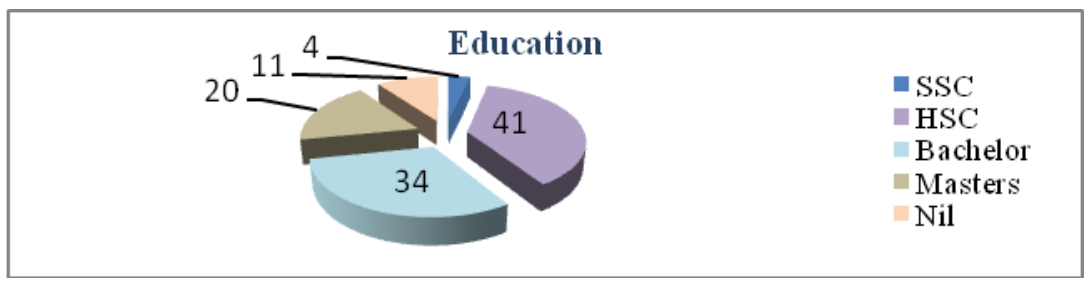

Figure 3: Demographic analysis

Use of Service: The following diagram shows the various types of financial services such as savings and withdrawal, payment/bill remittance, buy air time and transfer amount between accounts respondents are availing. It shows that all users are sending and withdrawing money through mobile. It also reveals that ATM and remittance are not as popular as other types of services.

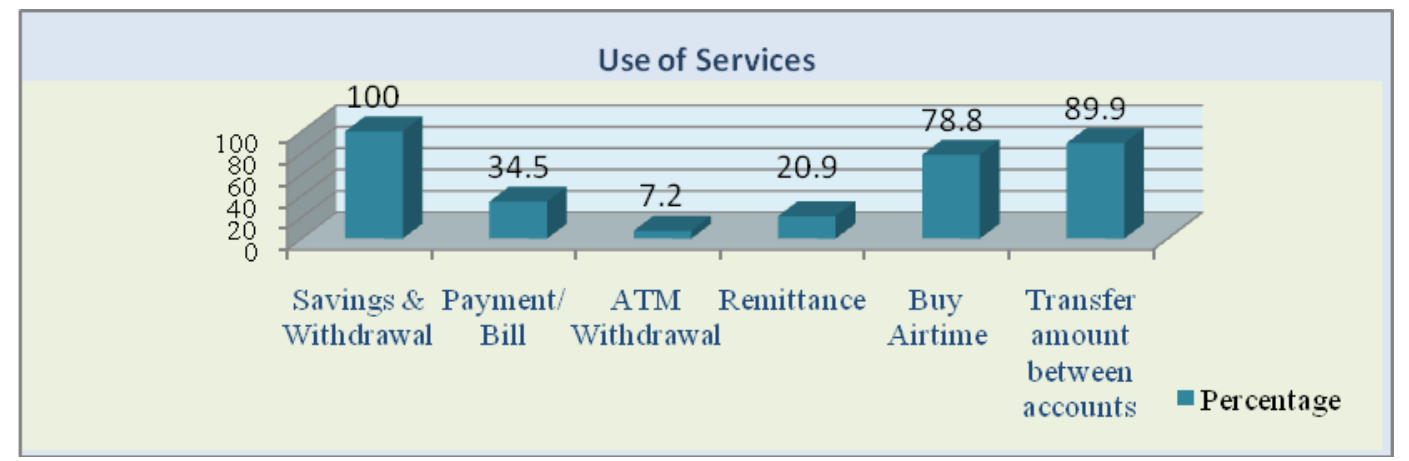

Figure 4: Use of services

Use of Financial Service Providers: Through the survey the study has found that, approximately $95 \%$ of people are using 'bKash', while 'Dutch Bangla mobile banking' is being used by $37 \%$. Approximately $2 \%$ for 'mCash', $4 \%$ for

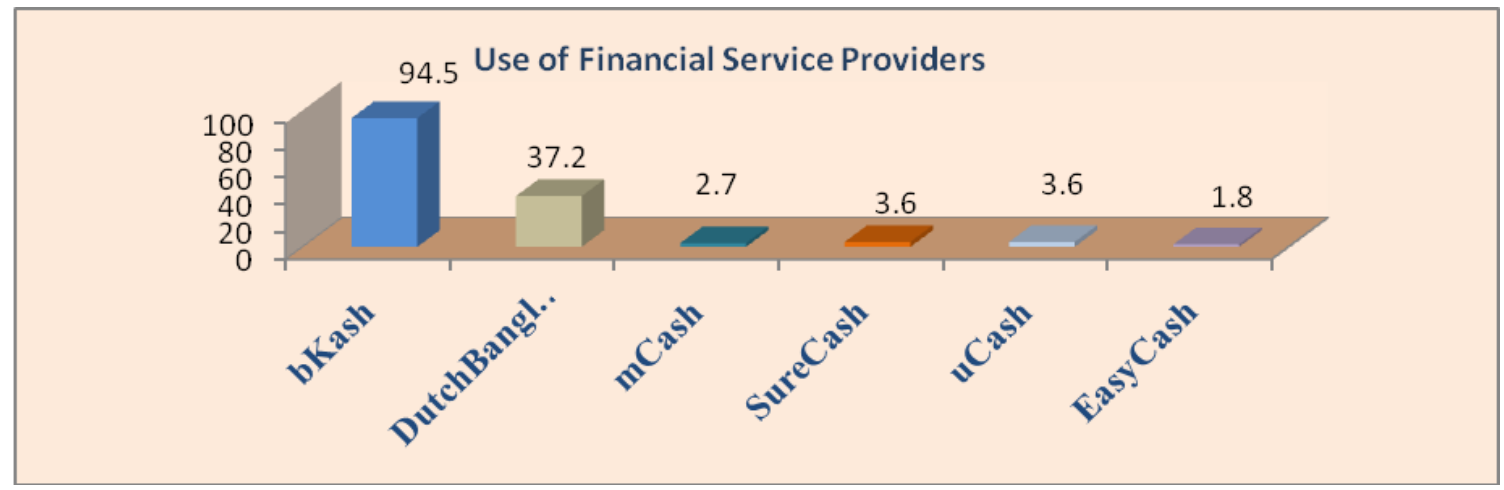

Figure 5: Use of financial services

'SureCash', 4\% for 'uCash' and approximately 2\% for'EasyCash'. Another thing is, most of the personal account holders use bKash or Dutch Bangla. The result for mCash, SureCash, uCash and EasyCash have been found from agents. 
Business Review- A Journal of Business Administration Discipline, Khulna University, Volume: 12, Number: 1E2, January-December 2017, pp.1-8 (Print ISSN : 1811-3788; Online ISSN : 2664-3502)

Mobile Operator Used in Financial Services: The survey has found that, approximately $43 \%$ of accounts are opened with Grameen Phone number. Almost 56\% of accounts are being operated by Bangla Link connection. 27\% uses Robi. And approximately $11 \%$ are being used by Airtel. The survey hasn't found any mobile bank.

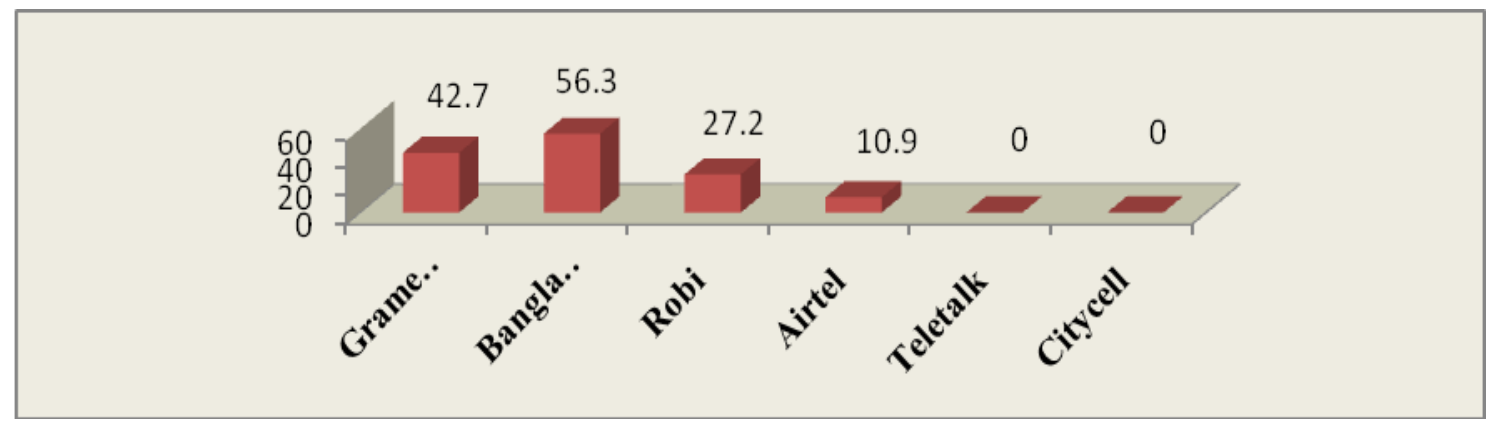

Figure 6: Mobile operators used in financial service

\begin{tabular}{|c|c|c|c|c|c|c|c|}
\hline & $\begin{array}{l}\text { Perceived } \\
\text { Usefulness }\end{array}$ & $\begin{array}{l}\text { System } \\
\text { Quality }\end{array}$ & $\begin{array}{c}\text { Ease } \\
\text { of Use }\end{array}$ & $\begin{array}{l}\text { Perceived } \\
\text { Credibility }\end{array}$ & Trust & $\begin{array}{c}\text { Social } \\
\text { Influence }\end{array}$ & $\begin{array}{c}\text { Intention } \\
\text { to Use }\end{array}$ \\
\hline \multirow{3}{*}{$\begin{array}{c}\text { Perceived } \\
\text { Usefulnes } \\
\text { s }\end{array}$} & 1 & $.578 * *$ & $.306 * *$ & $.413 * *$ & $.510 * *$ & -.028 & $.257 * *$ \\
\hline & & .000 & .001 & .000 & .000 & .385 & .003 \\
\hline & & 110 & 110 & 110 & 110 & 110 & 110 \\
\hline \multirow{3}{*}{$\begin{array}{l}\text { System } \\
\text { Quality }\end{array}$} & & 1 & $.402 * *$ & $.610 * *$ & $.546 * *$ & .015 & $.451 * *$ \\
\hline & & & .000 & .000 & .000 & .438 & .000 \\
\hline & & & 110 & 110 & 110 & 110 & 110 \\
\hline \multirow{3}{*}{$\begin{array}{l}\text { Ease } \\
\text { ofUse }\end{array}$} & & & 1 & $.533 * *$ & $.609 * *$ & .025 & $.483 * *$ \\
\hline & & & & .000 & .000 & .396 & .000 \\
\hline & & & & 110 & 110 & 110 & 110 \\
\hline \multirow{3}{*}{$\begin{array}{c}\text { Perceived } \\
\text { Credibilit } \\
\mathrm{y}\end{array}$} & & & & 1 & $.699 * *$ & .086 & $.505 * *$ \\
\hline & & & & & .000 & .186 & .000 \\
\hline & & & & & 110 & 110 & 110 \\
\hline \multirow[t]{3}{*}{ Trust } & & & & & 1 & .045 & $.620 * *$ \\
\hline & & & & & & .322 & .000 \\
\hline & & & & & & 110 & 110 \\
\hline \multirow{3}{*}{$\begin{array}{c}\text { Social } \\
\text { Influence }\end{array}$} & & & & & & 1 & .120 \\
\hline & & & & & & & .106 \\
\hline & & & & & & & 110 \\
\hline $\begin{array}{c}\text { Intention } \\
\text { to Use }\end{array}$ & & & & & & & 1 \\
\hline
\end{tabular}

The above table shows simple correlation between each pair of variables. The result is presented in the form of a correlation matrix. In case of perceived usefulness there is strong relation with system quality. For ease of use trust and perceived credibility have strong relation. Social influence has no strong relation with other variables. Finally intention to use has strong relation with trust and perceived credibility.

\section{Multiple Regression Analysis}

The statistical significance of the linear relationship between intention to use mobile financial services as dependent variables and independent variables (Perceived usefulness, system quality, trust, credibility etc) are tested by 
Business Review- A Journal of Business Administration Discipline, Khulna University, Volume: 12, Number: 1E2, January-December 2017, pp.1-8 (Print ISSN : 1811-3788; Online ISSN : 2664-3502)

examining the hypotheses. On the basis of the literature review six hypotheses have been developed. The hypotheses are as follows.

$\mathrm{H}_{1}$ : Perceived usefulness has impact on intention to use mobile financial services

$\mathrm{H}_{2}$ : System quality has impact on intention to use mobile financial services

$\mathrm{H}_{3}$ : Ease of use has impact on intention to use mobile financial services

$\mathrm{H}_{4}$ : Perceived credibility has impact on intention to use mobile financial services

$\mathrm{H}_{5}$ : Trust has impact on intention to use mobile financial services

$\mathrm{H}_{6}$ : Social influence has impact on intention to use mobile financial services

The null hypothesis implies that there is no linear relationship between dependent (intension to use) and independent variables (Perceived usefulness, system quality, trust, credibility etc). Alternative hypothesis implies that there is a relationship-positive or negative between the variables. From the table given bellow, it is found that two hypotheses are accepted and rests of them are rejected.

Table 02: Model Summary

\begin{tabular}{|c|c|c|c|c|}
\hline Model & R & R Square & Adjusted R Square & $\begin{array}{c}\text { Std. Error of the } \\
\text { Estimate }\end{array}$ \\
\hline 1 & $.665^{\mathrm{a}}$ & .442 & .409 & .56681 \\
\hline \multicolumn{2}{|r|}{ a. Predictors: (Constant), Social Influence, System Quality, Ease of Use, Perceived Usefulness, Perceived Credibility, Trust } \\
\hline
\end{tabular}

Table 03: ANOVA

\begin{tabular}{|l|c|c|c|c|c|c|}
\hline \multicolumn{2}{|c|}{ Model } & Sum of Squares & df & Mean Square & F & Sig. \\
\hline \multirow{3}{*}{1} & Regression & 26.182 & 6 & 4.364 & 13.582 & $.000^{\text {b }}$ \\
\cline { 2 - 7 } & Residual & 33.091 & 103 & .321 & & \\
\cline { 2 - 6 } & Total & 59.273 & 109 & & & \\
\hline & a. Dependent Variable: Intentiontouse \\
\hline & $\begin{array}{l}\text { b. Predictors: (Constant), Social Influence, System Quality, Ease of use, Perceived Usefulness, Perceived } \\
\text { Credibility, Trust }\end{array}$
\end{tabular}

Table 04: Regression Statistics

\begin{tabular}{|c|c|c|c|c|c|}
\hline \multirow[t]{2}{*}{ Model } & \multicolumn{2}{|c|}{ Unstandardized Coefficients } & \multirow{2}{*}{$\begin{array}{c}\begin{array}{c}\text { Standardized } \\
\text { Coefficients }\end{array} \\
\text { Beta }\end{array}$} & \multirow[t]{2}{*}{$\mathbf{t}$} & \multirow[t]{2}{*}{ Sig. } \\
\hline & $\mathrm{B}$ & Std. Error & & & \\
\hline (Constant) & 1.010 & .819 & & 1.233 & .220 \\
\hline Perceived Usefulness & -.173 & .103 & -.159 & -1.677 & .097 \\
\hline System Quality & .202 & .103 & .206 & 1.968 & .052 \\
\hline Ease of Use & .231 & .158 & .139 & 1.467 & .146 \\
\hline Perceived Credibility & .023 & .095 & .027 & .241 & .810 \\
\hline Trust & .382 & .094 & .482 & 4.069 & .000 \\
\hline Social Influence & .130 & .113 & .085 & 1.144 & .255 \\
\hline
\end{tabular}

In Table 2, $\mathrm{R}$ Square is .442 that signifies 44.2 percent variation of intention to use mobile financial service is explained by perceived usefulness, system quality, ease of use, perceived credibility, trust and social influence. Table 3 shows that $\mathrm{F}=13.582$ which is statistically significant $(\mathrm{p}<.05)$ so the data fit with the model well. Trust has 
Business Review- A Journal of Business Administration Discipline, Khulna University, Volume: 12, Number: 1E2, January-December 2017, pp.1-8 (Print ISSN : 1811-3788; Online ISSN : 2664-3502)

statically significant relationship with intention to use mobile financial services $(\mathrm{p}<.05)$ thus hypothesis 5 is has received sufficient supports for acceptance. System quality, ease of use, perceived credibility, and social influences have positive relationships with intention to use but not statistically significant ( $\mathrm{p}>$.05). Therefore, $\mathrm{H}_{2}, \mathrm{H}_{3}, \mathrm{H}_{4}$ and $\mathrm{H}_{6}$ have not received sufficient evidence for acceptance and it can be concluded that those variables do not affect customer intention to use mobile financial services. On other hand, perceived usefulness has negative relationship and it is not statistically significant. Thus, this study fails to provide sufficient evidence in favor of hypothesis 1 .

\section{Implications}

The study has many implications among the mobile financial service providers, mobile operators and users. From the providers' (i.e. banks) perspective, the advantages of mobile phone banking are enormous. Mobile banking helps banks penetrate underserved markets and reach out to remote localities in a cost effective way (Talukder et.al, 2014). This aspect of mobile phone banking is particularly important in the Bangladeshi context because many underserved populations are located in regional and rural areas. It has been stated that mobile-as-Internet-machine can allow customers to transact remotely (sending remittances, paying bills) without having to physically access a service point (Rosenberg, 2008). The survey result would certainly help the providers to set appropriate strategies to offer better services as well as to attain more customers. From user perspectives, the users will be able to know what are the available services mobile banking offering, which service most users are adopting and which operators the customers are using more -all these will help customer to take appropriate decision regarding mobile, financial services. For mobile operators, this study will let them to know their status among the users which ultimately help them to set strategies to win more market share and become more competitive.

\section{Conclusion}

Access to formal financial services can help households to better plan and manage their lives. Mobile Financial System (MFS) offers the opportunity to build another channel beyond the bank branch and ATM network to enable millions to have easier access to the formal banking system. The study has found an overall positive attitude of respondents to mobile financial services. There are some issues that can be recommended as for example MFS providers should take initiatives to avoid network problems. They should develop or bring new updated technologies that can work smoothly in huge load capacity.MFS providers should ensure more securities of technologies and should make awareness among customers and agents as well. The MFS provider should monitor its activity all over the country. As the result shows strong relationship between intention to use MFS and trust; it is important that mobile phone operators and MFS providers should work hard to keep mutual trust strong enough which is very important for the success of business. The findings can't be generalized as a small sample has been taken to conduct the study. Moreover, the study was confined within the urban area so; further study can be conducted by including both urban and rural users as well as by increasing the sample size which can generate better result.

\section{References}

Abrahamson, E. and Rosenkopf, L.(1997), 'Social network effects on the extent of innovation diffusion: A computer simulation', Organization Science, Vol. 8, No 3, pp.289-309.

Agarwal, R.and Prasad, J.(1998), 'The antecedents and consequents of user perceptions In information technology adoption', Decision Support Systems, Vol. 22, No. 1, pp.15-29.

Ajzen, I and Fishbein, M.(1980), 'Understanding attitudes and predicting social behavior', Englewood Cliffs, New Jersey, Prentice-Hall.

Al-Gahtani, S and King, M. (1999), 'Attitudes, satisfaction and usage: Factors contributing to each in the acceptance of information technology', Behavior \& Information Technology, Vol. 18, No. 4, pp. 277-297.

Anderson, T.(2007), 'Mobile phones lifeline for world's poor', Available at http://news.bbc.co.uk/2/hi/business/6339671.stm, (Accessed on 2 October 2018).

Aakash, M. Denny, G. Graham, A.N. Wright, Leena, A. Maha, K. Mike Mc., and Pawan, B.,( 2014), Agent network accelerator survey: Bangladesh Country Report 2014', Available at: http://www.helix-institute.com/data-andinsights/agent-network-accelerator-survey-bangladesh-country-report-2014 ( Accessed on 21 January 2017). 
Business Review- A Journal of Business Administration Discipline, Khulna University, Volume: 12, Number: 1E2, January-December 2017, pp.1-8 (Print ISSN : 1811-3788; Online ISSN : 2664-3502)

Beal, D \& Ralston, D.(1997), 'Economic and Social Impacts of the Closure of the Only Bank Branch in Rural Communities', Centre for Australian Financial Institutions, University of Queensland, report prepared for Credit Care.

Benassi, P.(1999), ‘TRUSTe: An online privacy seal program', Communication of the ACM, Vol. 42, No. 2, pp. 5659.

Bhattacherjee, A. and Sanford, C. (2006), 'Influence processes for information Technology acceptance: An elaboration likelihood model', MIS Quarterly, Vol. 30, No. 4, pp.805-825.

Brown, I, Cajee, Z. Davies, D. and Stroebel, S.(2003), 'Cell phone banking: predictors of adoption in South Africaan exploratory study', International Journal of Information Management, Vol. 23, No. 5, pp. 381-394.

Bruner, G. and Kumar, A.(2005), 'Explaining consumer acceptance of handheld Internet Devices', Journal of Business Research, Vol. 58, No. 5, pp. 553-558.

Chang, M. and Cheung, W.(2001), 'Determinants of the intention to use Internet/WWW at work: A confirmatory study', Information \& Management, Vol. 39, No. 1, pp. 1-14.

Chen, L. and Tan, J. (2004), 'Technology adaptation in electronic commerce: key determinants of virtual store acceptance', European Management Journal, Vol. 22, No. 1, pp. 74-86.

Davis, L. D., Bagozzi, R. P., and Warshaw, P. R. (1989), "User acceptance of computer technology: A comparison of two theoretical models", Management Science, Vol. 35, No. 8 , pp. 982-1003.

Fishbein, M. and Ajzen, I. (1975), Belief, Attitude, Intentions and Behavior: An Introduction to Theory and Research, Boston.

Greg, C.(2012), 'The Growth of Mobile Financial Services in Bangladesh', Magazine, viewed on 21 October 2015,<http://www.cgap.org/blog/growth-mobile-financial-services-bangladesh>.Helix Institute of Digital Finance, viewed 14 November 2015,<http://www.helix-institute.com/data-and-insights/agent-networkaccelerator-survey-bangladesh-country-report-2014>.

Luarn, P., and Lin, H.H. 2004,'Toward an understanding of the behavioral intention to use mobile banking', Computer in Human Behavior, vol. 21, no. 6, pp. 340-348.

Shi Y.(2009), 'Factors influencing the use of Mobile Banking: The case of SMS-based Mobile Banking', MCIS thesis, Auckland University of Technology, New Zealand.

Ahmed, S.M., Rayhan, S.J, Islam, M.A., and Mahjabin, S.M. (2012), 'Problems and prospects of mobile banking in Bangladesh', International Journal of Capacity Building in Education and Management, Vol. 1, No 1, pp. 4362.

Mohajon, S.(2015), '9.5 lakhs users increased within one month', Economy, Online newspaper, viewed 7 November 2015, <http://www.prothom- alo.com/economy/article/672769.

Talukder, M, Quazi, A and Sathye, M. (2014), 'Mobile Phone Banking Usage Behaviour: An Australian Perspective', Australasian Accounting, Business and Finance Journal, Vol. 8, No. 4, pp. 83-104.

Tribune report, 9 October 2014, 'Mobile financial services a boon for all', viewed 10 November 2015, Dhaka Tribune, <http://www.dhakatribune.com/editorial/2014/oct/09/mobile-financial- services-boon-all> .

Tribune report, (2014), 'BB gets international award for promotion of mobile banking', viewed 10 November 2015 , Dhaka Tribune, <http://www.dhakatribune.com/banks/2014/sep/11/bb-gets-international-award-promotionmobile-banking>. 